\title{
Information technology and communication and best practices in it lifecycle management
}

\author{
Francisco Carlos Paletta (I), Nilson Dias Vieira Junior (2)
}

\begin{abstract}
In this work, we focus on the role of Information and Communication Technologies - ICT - to create additional sources of competitive advantage that can help companies to prepare themselves for sustainable growth in the long term. First, we discuss the dynamics of ICTs and the ability to generate innovations with a direct impact on business. Then we present the need for greater balance between goals of short and long term on IT projects. In the third part, we discuss how these new technologies have helped to increase the productivity of information professionals as well as to enhance decision-making process and the satisfaction of the end customer. To conclude, it is presented the main challenges that the technology-based companies will have to face in relation to the management of the lifecycle of their technology, consolidation and simplification of their processes within their computing environments, aiming to increase productivity and develop agile environments that allow the organizations to meet the demands of managing digital information.
\end{abstract}

Keywords: Information Technology, Innovation, IT Lifecycle Management.

(I) Instituto de Pesquisas Energéticas e Nucleares - IPEN.Av. Prof. Lineu Prestes, 2242 - Cidade Universitária - 05508-000 São Paulo SP.Brazil.fpaletta@ipen.br

(2) Instituto de Pesquisas Energéticas e Nucleares - IPEN. Av. Prof. Lineu Prestes, 2242 - Cidade Universitária - 05508-000 São Paulo SP.Brazil.nilsondv@ipen.br 


\section{Introduction}

For many organizations, the increasing availability of technologies has shown an ambiguity in their management. The management and support of these complex and heterogeneous environments - full of different PCs, desktops and laptops, mobile and wireless devices, printers, networks and applications have demonstrably proven difficult and expensive for the departments of Information Technology.

According to OECD (2002), the Information and Communication Technologies (ICTs) play important and growing role in world economy, and companies, industries and governments are getting increasing benefits from their continuous investments in ICTs, as well as from a wider use of the Internet in a knowledge-based economy. ICTs have stimulated innovation in services, increased the efficiency of production and creation, and at the same time, facilitated the management of inventories and administrative costs. It was a catalyst of changes in companies, improving the organization of work, helping companies to reduce the cost of their routine transactions and streamlining their supply chains. So crucial, ICTs, especially when associated with the raise of the level of skills and organizational change, apparently seem to support the improvement of productivity within enterprises, both in new sectors and in traditional branches. Such benefits have long term effects and will continue to develop, despite the difficulties and challenges with which companies are facing today.

Many new applications of Information and Communication Technologies have a potential meaning and may have economical and social impacts, as well as a key role in the bonding and in the convergence of the various technologies. Among these emerging technologies are the ubiquitous networks, which enable monitoring of people and objects as well as tracing, storing and processing of information in real time.Applications such as radio frequency identification (RFID) and other technological sensors are being used in applications for commercial use. The technology of prevention and warning of natural disasters are becoming more important for reducing the impacts of disasters which result in large economic losses. The participatory Web (Web 2.0) is the active participation of users on the Internet, creating contents, they adapt the Internet and develop applications for a wide variety of fields. The digital content represents an important factor in the ICT industry. Technological innovation and demand of new consumers are leading to new forms of creation, distribution and access to digital content. The convergence in applications such as convergence of nanotechnology, biotechnology, neurotechnology, robotics and information technology, probably, will provide more opportunity and challenges for companies operating in the sector (OECD, 2006).
Based on this scenario, this article proposes to examine the critical factors that should be considered by technology-based companies in managing the lifecycle of their resources for information technology with a focus on organizational performance.

\section{Information and Communicaction Technologies - ICTs}

As from the World Summit on the Information Society (WSIS) held in Geneva in 2003, countries and regions were invited to develop tools to measure and monitor progress toward the "information society", including basic indicators of information and communication technology - ICT.

The summit marks the start of a geopolitical process led by the United Nations and the International Telecommunication Union. Therefore, a crucial period in terms of multilateral negotiations that might lead to a new level of global governance of digital networks, guided by the quality of the indicators of inclusion, digital access or connectivity (FAPESP, 2004).

Digital convergence among telephony, Internet and telecommunications (radio and TV) foresee changes of great magnitude and depth not only in behaviors and human institutional relations, but also in the patterns of connection among the infrastructures of all sectors of the economic social life. "These changes have as a determining factor the development of information communication technologies operated by means of interactive digital networks" (FAPESP, 2004).

In a search of measurement held by the United Nations (UN) in 2004, 179 countries received the questionnaire. In Latin America and the Caribbean, more than half of the twenty countries surveyed have no formal definition for ICT; six countries implemented some sort of definition and there are developing one (UN, 2005).

According to the report, Information Technology (IT) can be summarized as a set of all activities and solutions provided by computing resources and, with applications related to several areas. Information Technology is also commonly used to denote the set of non-human resources dedicated to storage, processing and communicating information as well as the mode of how these resources are organized in a system capable of executing a set of tasks. IT is not limited to equipment (hardware), software (software) and data communications. There are technologies for the planning of Computing, for the development of systems, for the support, for the software, for the processes of 
production and operation and for the support of hardware. The acronym IT covers all activities developed in society by using the resources of computers.

Living in the scenario of research and development of ICTs, the perception of the revolutionary character and a unique set of problems in the field of measurement, interpretation and, therefore, decision-making (FAPESP, 2004). Comparative statistics on access and use of ICT are critical to the formulation of policies and strategies for the growth of ICT, aiming at social inclusion and cohesion to monitor and assess the impact of ICT on the economic and social development (UN, 2005).

\section{I ICT Indicators and E-Commerce}

In the telecommunications industry to voice remains the main driver of the telecommunications markets of member countries of the OECD, which yields millions of dollars with it. The mobile services make up $40 \%$ of all income from telecommunications in the region of the OECD, and subscribers to mobile services go beyond those from fixed network at a rate of three to one (3:I). At the same time, technologies such as Voice over Internet Protocol (VolP) make strong pressure on prices for voice services. Broadband has become the dominant technology for Internet access at the OECD; $60 \%$ of the 256 million of Internet subscribers have broadband connection. Providers of cable services often offer data and voice, while mobile service companies complement those offerings with packets of data and video, and traditional telecommunications providers offer similar multiple products on networks(OECD, 2007).

A basic and practical form of referring to e-commerce is used by the Internet Management Committee in Brazil (CGI, 2007): "purchase or sale of goods or services by means of computer networks, based on Internet protocols or other networks mediated by computers."

The definition does not take into account the competitive advantages resulting from the combination of the participants of supply chains and value (the people involved in the flow of goods, services, money and necessary information to bring the products from raw materials to the hands of consumers).

In that sense, e-commerce includes any business that takes place directly between business partners or customers through a combination of computing and communication technology (LUCIANO, 2003 apud TREPPER, 2000).

Electronic commerce is causing intense changes in the organization of companies as well as in their relationship with customers, partners and suppliers, inaugurating a new era in world business.
Behind the simple and apparent change in the way of buying, there are changes in the economy, industry organization, legislation, jobs, forms of consumption, relationships and value creation (LUCIANO, 2003)

According to Viotti and Macedo (2003). In Brazil, in 1999, the segment B2B ("business to business", or commercial transactions between companies) had revenue of 50.4 billion dollars, against 30. I billion segment of B2C ("business to consumer", or company with final consumer).

Nearly half of the people who have used the Internet said that they have conducted searches in price of goods or services in the net $(45 \%)$ in 2007 , while only $16 \%$ reported to have finalized na purchase through the web.

The data shows that the Internet has consolidated itself as a tool for comparing costs and surveying the availability of goods and services, even if the process of finalizing the purchase of the product does not happen through it (CGI, 2007).

According to the Brazilian Chamber of Electronic Commerce (2005), the revenue from e-commerce in Brazil had nominal growth of $400 \%$ over the past five years. Moreover, a survey commissioned by the Board e.net shows that between 2003 and 2004 , the value traded by e-commerce, among businesses and Brazilian consumers, represented $4.22 \%$ of total trading done in Brazil.

Figure I, with e-commerce data from Brazil (200I-2005), and Figure 2 with data from world e-commerce (I999-2004), allowing compare Brazil's position in relation to the other countries surveyed. The industry in Brazil should reach the mark of 2.8 billion reais in 2010 , according to study conducted by Forrester Consulting (CECB, 2005). Evaluating the data in graphs, it is possible to have a vision of the sums involved and of the status of E-commerce in Brazil and in the world.

\subsection{Internet and ICT in Brazil and in OECD}

The ICT sector is one of the most dynamic in trade of goods and services in foreign direct investment focused on exports, mergers and acquisitions, particularly in telecommunications. In 2003, more than 14.4 million people were employed in the area of ICT in OECD countries, or $5.5 \%$ of the workforce: five million in manufacturing and 9.5 million in services (OECD, 2006).

The trade in ICT has expanded rapidly in the 1990s, growing more than $20 \%$ in 2000 . In 200 I there was a slowdown, and a decline in demand was heavy, with a strong recovery in 2003 and 2004. Growth had remained steady in the same values in 2005 and, for 2006, it was expected to maintain the same rates 


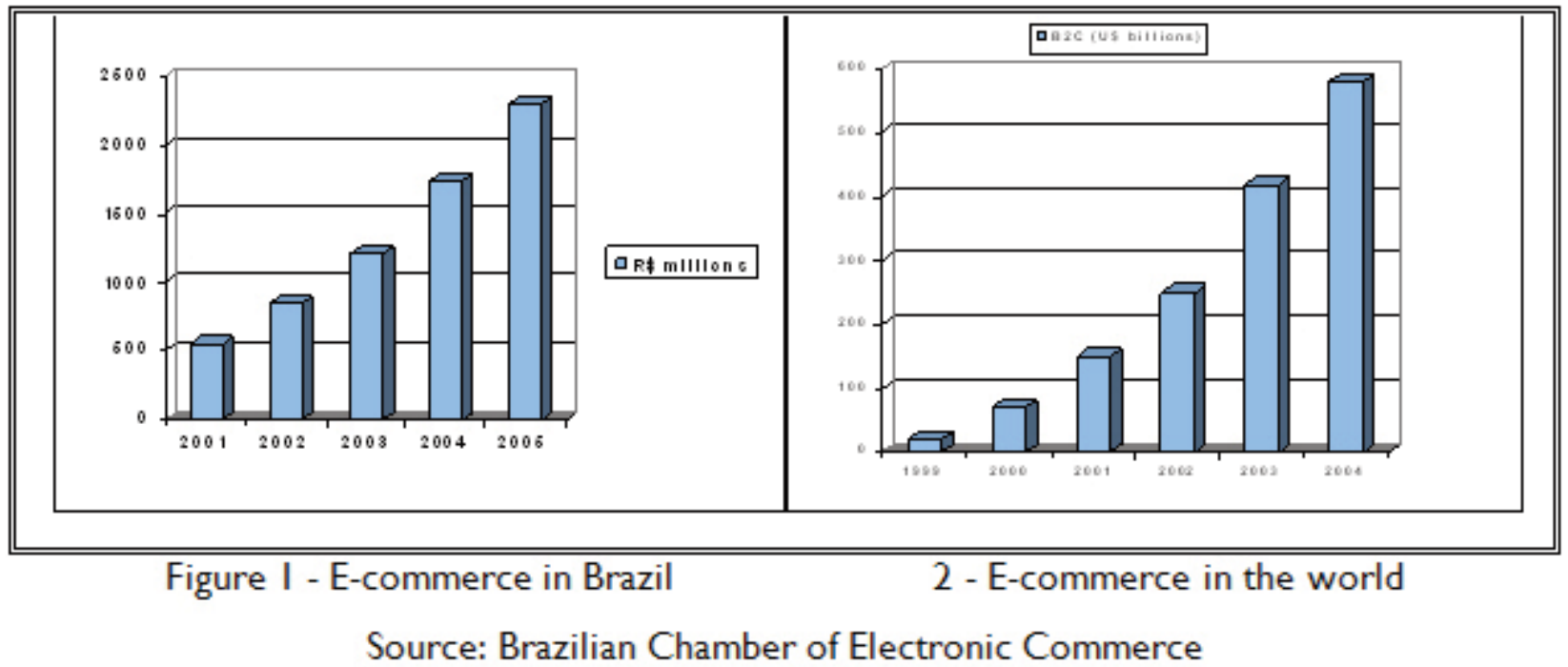

in the production, with higher growth in some segments, especially in trade with developing countries like China (OECD, 2006).

Csillag and Graeml (2005) sought to evaluate the intensity of use of the Internet and other IT tools; their impact on the processes and activities of companies between 2001 and 2004; and the intention of adopting the tools in the next three years. The sample comprised 665 companies from the database of the Federation of Industries of São Paulo state, since the state accounts for $36.6 \%$ of the jobs of Brazilian industrial sectors and $49.1 \%$ of the national industrial transformation value (ITV).

The results show that many tools adopted abroad are underused in Brazil. Although most companies have their own site, the use is basically as a window of products, without generation of revenue. Electronic commerce, for example, is little explored, and conferences through the net and chat rooms are almost absent from the organizational environment, although they are promising tools for communication among professionals in the company, suppliers and customers.

At least $20 \%$ of companies participating in the research of Csillag and Graeml believe that the Internet and other technologies of information were responsible for considerable change in most of its processes and activities in the past three years. It was also verified that almost three quarters of large companies already try to obtain responses from customers through the site, and half use them to after-sales service. According Csillag and Graeml, this suggests that the industry is discovering that provide the best service for customers can be a powerful argument to differentiate the product from the competition and gain competitive advantage.
Another positive point is the increased interest by e-procurement, corporate tool used for shopping on the Internet. Furthermore, the literature cited by the authors show that the dominance of institutional sites is not in itself a setback for ecommerce, as it might seem. According to them, institutional sites tend to be a test for commercially-aggressive sites, as well as the purchase of non-productive materials by the Internet tends to be a test for the purchase of productive materials, which is more central to the business.

The Internet and the rapid expansion of mobile telephony have transformed the segment of communications equipment in one of those which had the fastest growth in ICT since 1996, with exports from OECD countries having doubled between 1996 and 2000.The biggest exporters were Korea, Germany and the United States. IT equipment form the largest market for ICT, with one third of the total negotiated, and Korea and Ireland are still the largest producers (OECD, 2006).

In Brazil, liberalization of the ICT market in the early 1990s had greater impact on the sector of information technology; changes in telecommunications happened later, with the General Telecommunications Law (VIOTTI \& MACEDO, 2003). Table I shows, via "hosts", the growth of Internet in Brazil, whose index is high even when compared to developed countries.

In 2007, the Internet reached 17\% of the total of Brazilian homes, representing a growth of 3 percentage points over the previous year. Broadband connections are already present in $50 \%$ of Brazilian houses that have Internet access, but $42 \%$ still connect to the network primarily by traditional modem access via dial. In 2006, dial access was predominant, with $49 \%$, while broadband connections accounted for $40 \%$ of the types of 


\begin{tabular}{|c|c|c|c|c|c|}
\hline & \multicolumn{5}{|c|}{ Maps of countries by number of hosts (ISP's) } \\
\hline & \multicolumn{3}{|c|}{ Jan.//998 } & \multicolumn{2}{|c|}{$\operatorname{Jan} . / 2008$} \\
\hline Itt & United States* & 20.623 .995 & Ist & United States* & 302.884 .146 \\
\hline $2^{\text {nd }}$ & Japan (.jp) & 1.168 .956 & $2^{\text {nd }}$ & Japan (.jp) & 36.803 .719 \\
\hline $3^{\text {rd }}$ & United Kingdom (.uk) & 987.733 & $3^{\text {rd }}$ & Germany (.de) & 20.659 .105 \\
\hline $4^{\text {th }}$ & Germany (.de) & 994.926 & $4^{\text {th }}$ & Italy (.it) & $|6.730 .59|$ \\
\hline $5^{\text {th }}$ & Canada (.ca) & 839.141 & $5^{\text {th }}$ & France (.fr) & 14.356 .747 \\
\hline $6^{\text {th }}$ & Australia (.au) & 665.403 & $6^{\text {th }}$ & China (.cn) & 13.113 .985 \\
\hline $7^{\text {th }}$ & Netherlands (.nl) & 381.172 & $7^{\text {th }}$ & Australia (.au) & 10.707 .139 \\
\hline $8^{\text {th }}$ & Finland (.fi) & 450.044 & $8^{\text {th }}$ & Netherlands (.nl) & 10.540 .083 \\
\hline $9^{\text {th }}$ & France (.fr) & 333.306 & $9^{\text {th }}$ & Brazil (.br) & 10.151 .592 \\
\hline $10^{\text {th }}$ & Sweden (.se) & 319.065 & $10^{\text {th }}$ & Mexico (.mx) & 10.071 .370 \\
\hline $11^{\text {th }}$ & Italy (.it) & 243.250 & $11^{\text {th }}$ & United Kingdom (.uk) & 7.727 .550 \\
\hline $12^{\text {th }}$ & Norway (.no) & 286.338 & $12^{\text {th }}$ & Poland (pl) & 7.134 .976 \\
\hline $13^{\text {th }}$ & Spanish (.es) & 168.913 & $13^{\text {th }}$ & Taiwan (.tw) & 5.121 .607 \\
\hline $14^{\text {th }}$ & Switzerland (.ch) & 114.816 & $14^{\text {th }}$ & Canada (.ca) & 4.717 .308 \\
\hline $15^{\text {th }}$ & Denmark (.dk) & 159.358 & $15^{\text {th }}$ & Finland (.fi) & 3.728 .551 \\
\hline $16^{\text {th }}$ & New Zealand & 169.264 & $16^{\text {th }}$ & Belgium (.be) & 3.618 .495 \\
\hline $17^{\text {th }}$ & Korea (.kr) & 121.932 & $17^{\text {th }}$ & Russia (.ru) & 3.577 .635 \\
\hline $18^{\text {th }}$ & Brazil (.br) & 117.200 & $18^{\text {th }}$ & Sweden (.se) & 3.513 .170 \\
\hline $19^{\text {th }}$ & Belgium (.be) & 87.938 & $19^{\text {th }}$ & Switzerland (.ch) & 3.308 .684 \\
\hline $20^{\text {th }}$ & South Africa (.za) & 122.025 & $20^{\text {th }}$ & Denmark (.dk) & 3.256 .134 \\
\hline \multicolumn{6}{|c|}{ (.edu, .us, .mil, .org, gov, .com, .net e .info) } \\
\hline Sourc & letwork Wizards. & ement $\mathrm{Co}$ & e of $t$ & Internet in Brazil & \\
\hline
\end{tabular}

Table I - Expansion of the Internet in Brazil and in the world (Jan.//998 and Jan./2008)

home access. The growth of broadband in the period was, therefore, by 10 percentage points (CGI, 2007).

\subsection{Risks and Benefits of Investment in it}

When it happens, the collapse in IT projects takes two forms. The first pattern of failure is marked by a lack of consensus on objectives and lack of confidence in the IT business of the company. Managers are hesitant to invest in major projects in IT, which results in lower budget for the area. In another standard, the IT and the businesses of the company align themselves, and
IT spending remains stable, but the managers resist to invest in something that is not intimately connected with the immediate needs of application in the business - the infrastructure becomes obsolete, the common basis of data does not grow and the system becomes complex and fragile. Since the collapse in IT has been avoided and confidence restored, companies must remain vigilant. The alignment between IT and business foundation is important and requires constant adjustment to keep IT in the right direction. (WESTERMAN, 2007)

The performance of the largest companies in ICT in recent 
years shows broad recovery from the sharp decline and recession that began in 2000 and was until 2002. Software, services and IT equipment have been growing consistently, but the conditions were much more challenging for business of communications equipment. The corporations need to find a balance between the extreme of not innovate in any way - and lost opportunities - and only innovation - and increase the risk and expense (FUJITSU, 2002).
The 250 largest companies in ICT had revenue of three trillion dollars, nearly 570 billion more than in 2000 , with average growth of $4 \%$ a year since then. The 250 largest firms employ 10 million people worldwide, with spending on $R \& D$ around I 35 billion (6.3\%) in 2005 (OECD, 2006). Figure 3 shows the market share of each sector of ICT in 2005.

A 2003 survey of IBM Businss Consulting Services with I50

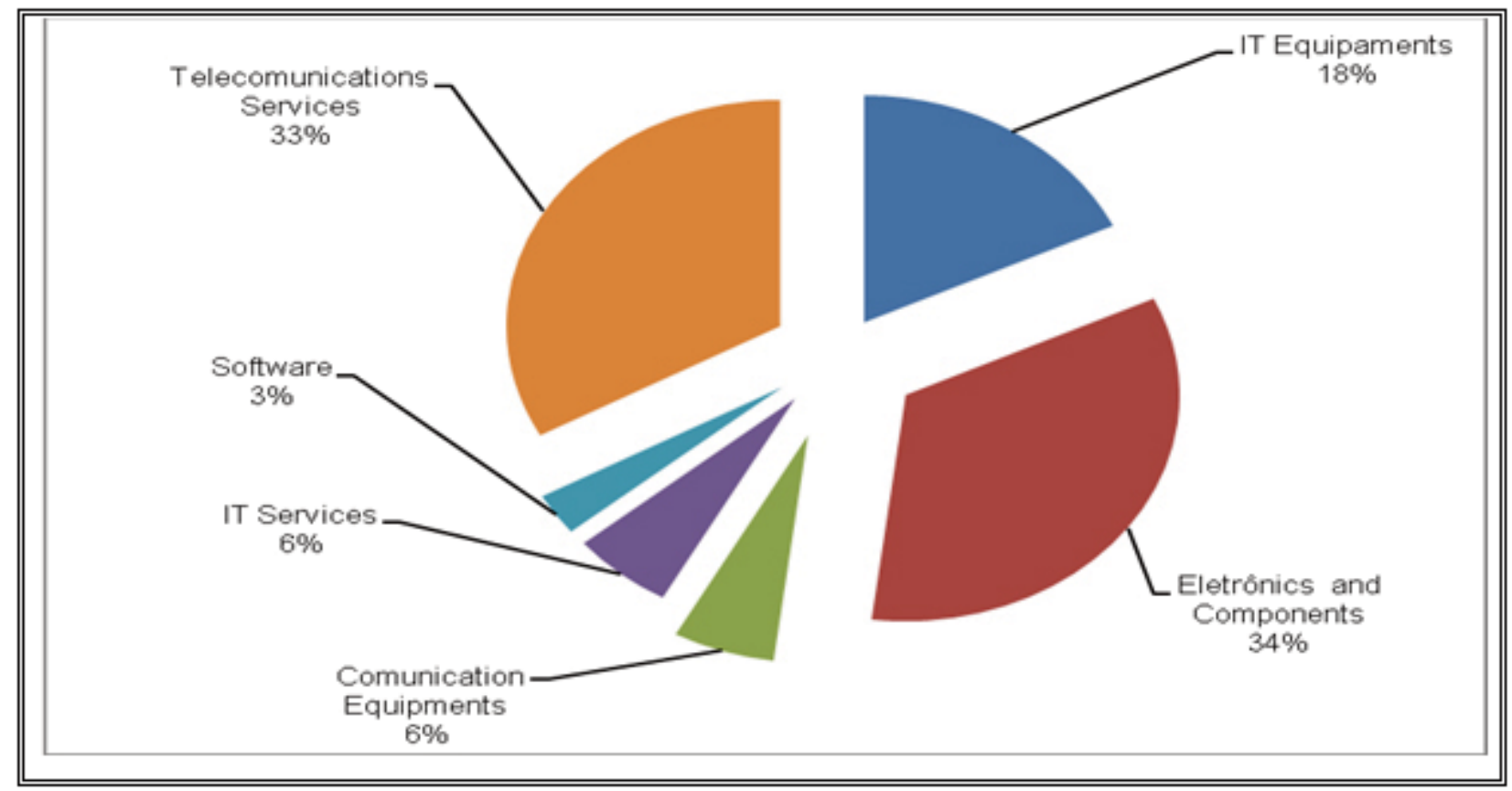

Figure 3 - Revenue per sector from 250 largest companies in ICT (2005). Source: OECD, 2006

companies based in Brazil with their internal customers show, among others, the need for greater balance between goals of short and long term projects in the IT (LOZINSKY, 2003).

Below are the findings of IBM study, together in six broad aspects.

- Strategic planning: the area should help with questions about the viability of corporate strategies and propose new solutions and alternatives, can not do strategic planning without any support from IT.

- Balance between short and long term: the pressure to reduce costs in the short term can not eliminate $R \& D$, under risk of the company fails to meet the challenges imposed by the competitive environment. It is up to with the IT enhance the individual abilities of each element of value chain, without necessarily bear all the costs and risks of these activities.
Governance: It is necessary to professionalize and classify the decision-making processes and provide the commitment, setting priorities for investment, monitoring IT contribution to business as well as the correct capture and allocation of the costs of the department to the areas which use them.

- Measuring of value: the area of IT needs to demonstrate results that can be understood by managers, which requires assessment systems in structured financial metrics and nonfinancial, internal and external, to assess the past and the prospects for the future, quantifying the benefits - not only the cost of the activity of IT.

IT relationship with users: IT must find a new way of interacting with internal clients, capturing expectations and surpassing them.

Sourcing: issues such as strengthening the relationship with 
a limited number of suppliers, standardization of items of equipment, renegotiation of supply contracts and review of procedures for the management of assets are rarely addressed in an appropriate manner in relation to IT.They are not problems of managing IT, but IT management. For most who write and talk about governance and management of portfolio of investments in IT, there was no such significant changes in these techniques to justify imagine problems that are distinct from those originally discussed by them. People, relationships, communication, planning and control must always be in the foreground.

\subsection{Scenarios of ICT}

Digital content has become a major driver of the ICT industry. Technological innovation and new consumer demand are leading to new and direct ways of addressing the creativity, new methods of distribution and improvement in access. Research results, for example, are becoming more accessible, and digital content is invading various sectors, for applications that may be more significant than the others for entertainment (OECD, 2006).

Continuous improvements in technology, networking, software and hardware, including cellular and wireless service and protection of content and services, have made possible the development of advanced digital content. Greater cooperation is a major challenge, since the production of digital content requires agreements between content developers, equipment manufacturers and distributors.

This successful implementation requires efficient services and low cost in infrastructure and technologies to protect content. Issues of compatibility and interoperability must also be resolved (OECD, 2006).

Significant number of companies wants to provide resources so that customers can track the progress of their orders through the Internet (49.8\%) over the next three years. That was one of the trends revealed when the study of Csillag and Graeml (2005) investigated the future intention towards the use of technology. The e-procurement (4I.8\%), the extranet to suppliers (4I.I\%) and customers (44.4\%), CRM (45.8\%) and electronics recovery (4I.2\%) are areas where major changes are expected.

In a research of Day and Hubbard (2005), with 352 executives about the impact of the Internet towards the ability of managing customer relationships, the reduction of costs in acquiring new customers was the most important variable for managers. However, the fact that customers can enlarge the field of action, compare prices quickly and eliminate transaction costs using the Internet, does not mean that they will abandon their current supplier.

Only 3\% of companies felt that a major factor threatening, while $14 \%$ saw it as an important opportunity. The possibility of reducing costs of customer service (self-service) was the second most important factor in the opinion of respondents, which reflects changes in the goals of CRM projects that fail to seek an increase in revenue in order to contain costs.

The responses to the 2005 OECD questionnaire (2006) about Policy on Information Technology indicate that government policies are mainly aiming at:

-The coordination and priority setting and general direction of policy in IT and its contribution to wider goals of economic policy;

\section{The promotion of innovation in the field of IT;}

- The dissemination and use (with emphasis on electronic government - eGov);

- Jobs and expertise in ICT;

- Digital content;

Business environment for ICT (with emphasis on intellectual property rights);

Strengthening the infrastructure (particularly broadband).

The term "broadband" is usually associated with Internet connections for high-speed cable. However, in recent years, companies started offering mobile phone services in large-band cellular network. An OECD study of 2006 found nearly $30 \%$ of mobile carriers offering $3 \mathrm{G}$ data connection, of third-generation (OECD, 2007).

The ability to leverage the potential of the technology is becoming increasingly critical to the success of organizations. The main tool to acquire this ability is to develop an effective organization of IT, focusing on three key areas:

- Definition of an organizational structure appropriate to the services and technological environments of the company;

- Development of processes and skills to centralize critical functions; 
- Model of governance structured to facilitate the alignment of service with responsibility for IT personnel.

\section{It Lifecycle Management}

The consolidated management of the working environment of IT requires that technology-based companies adopt a holistic approach directed to people, processes and technology throughout the computing environment. It also requires that organizations work with suppliers of IT that can analyze their operational needs, assisting the implementation and ongoing management and support of the solutions implemented.

According COEX (2005), the basic challenges that organizations face in the computing environments include:

Reduction of costs - The environments for customer service are moving quickly to mobile search locations, virtual and global, culturally diverse, which are expensive to maintain and support. Through the consolidation of hardware, applications and support processes within their working environments, organizations can manage and reduce IT costs, while simultaneously improving the return on investment.

Increased productivity of professionals of information - To achieve this goal, organizations are seeking ways to improve col- laboration and teamwork by creating a work environment without borders, reliable and secure, providing the connection and access to information anytime from anywhere.

Reducing the complexity of IT - The lack of standardization within the computing environment can increase the time and cost required to manage and support this environment. At the same time, as the computing environments become more complex, the level of knowledge and expertise needed to support them increases. The tools for managing the IT lifecycle allow the standardization of the hardware platform; reducing redundant devices; simplifies and automates the computational processes; besides managing the support functions and building flexibility and stability that allow the creation of a dynamic management of digital information.

The management of the IT infrastructure becomes increasingly expensive and complex. Studies indicate that more than $50 \%$ of all costs of IT are allocated to configure, upgrade, migrate and manage resources (O'BRIEN, 2002).

According to SILVER (2003), the largest expense of ownership of IT esources is not the initial purchase of hardware and software, but the complexity of implementing and maintaining these devices. To reduce these costs, organizations need to invest in management software systems to improve reliability and

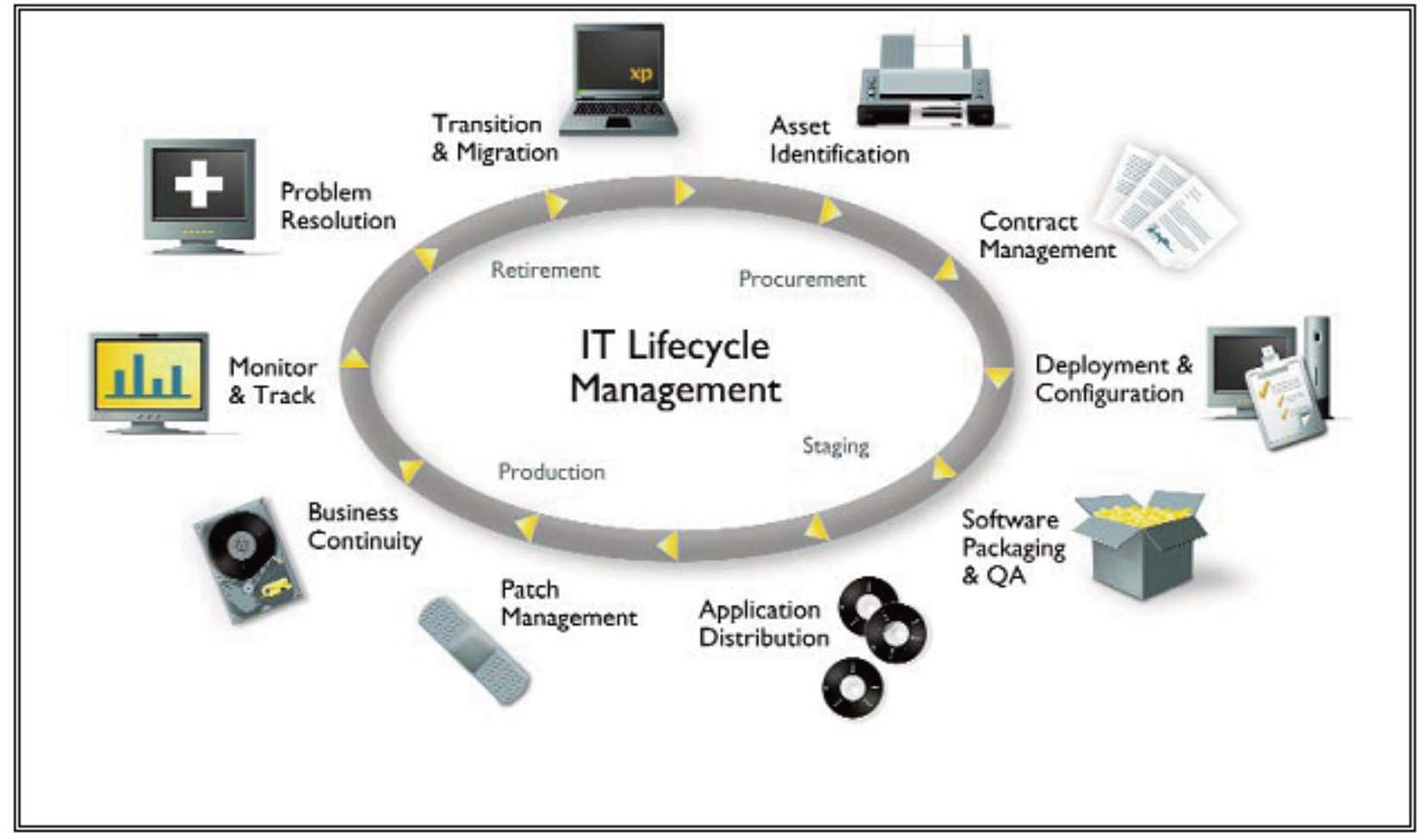

Figure 4 - IT Lifecycle Management Source:Altiris 
availability of hardware and software, through all phases of a resource lifecycle. Figure 4 shows the main stages of IT lifecycle management.

When evaluating a tool for IT lifecycle management, it is imperative to consider the following relevant features of the solution (SILVER, 2003):

- Management of the lifecycle of IT assets via Web;

- Identification and physical location of assets;

- Physical and logical setting - hardware devices and software;

- Monitoring of the use of software and hardware;

- Management of maintenance contracts for HD (Hardware) and SW (Software);

- Increased productivity of users, IT professionals and network devices;

- Resolution of problems ensuring the availability of resources and services;

- Diagnostics and real-time information for decision-making;

- Modular structure with flexible deployment;

- Integration via Web with database and repositories of information;

- Technical Support and Training of the user.

As stated by BROWM (2005), best practices for managing IT should allow adequate treatment to the complexities associated with the management of IT resources. The systems must be modular, allowing the definition of a technological structure compatible with the computing needs of the organization.

\section{I Resource Management, Mobile Equipment and Servers}

The increasing complexity of the technological assets has encouraged IT managers to seek ways to improve efficiency in the operation to reduce costs, adhere to the regulatory aspects and meet the constant demands of organizations for a better response from the department of IT. These factors have been a booster so that IT managers seek efficient ways to take control of everything that exists in their network.
According to ROCKART (1996), the eight requirements for an organization of IT to achieve operational excellence and maximize their performance are:

\section{I - Getting Strategic Alignment of "two hands" - between IT and "operation".}

- To be an effective strategic alignment between IT and business, it should occur in "two hands": the staff of IT should have a greater understanding of the operation and, concomitantly, the company's executives must keep in mind the potential that IT has to "leverage" or even change the business.

\section{2 - Develop effective relationships between IT and opera- tion.}

- As the line managers are key users of IT applications, there should be a close and continuous relationship between them and IT staff, at each level of the organization.

- Successful priority systems and close relationship leads to a better understanding of the operation and a cyclical process of progress and successes.

\section{3 - Deliver and deploy new systems.}

- Big change in the process of developing systems. The internal development of transactional systems for greater outsourcing, integrating information focused on re-engineered processes.

- Users less tolerant about long delays in development, inflexible interfaces and over-budgets.

- Placing of high-level line managers in the leadership of the projects, increasing the responsibility of future users with the system.

- External development and "packages" (for example, the "packages" ERP - Enterprise Resource Planning): faster and less expensive alternative of deployment.

- Manage this process is very different than in the case of external development.

\section{4 - Build and manage the infrastructure}

- Need for an infrastructure (in terms of computers, telecommunications, software and data) that enables the 
provision and integration of information throughout the network and for the re-engineered processes.

- Important for a "globalized" operation.

- Basic points for this infrastructure: architecture, patterns and team's ability to operate the IT infrastructure

\section{5 - Re-train (Reskill) the IT Organization}

- Need of IT staff be re-trained in new ways and methods of development, such as client-server architecture, new languages and communication protocols.

- Training in skills and knowledge of the business itself, since IT is increasingly important and ubiquitous in all organizations. How to promote this training is not consensus among businesses yet.

\section{6 - Manage partnerships with suppliers}

- Outsourcing: is the alternative to supply deficiencies of certain skills in IT, especially those that are not core competencies or competitive differentials.

- In addition to any economy, would allow high IT directors to focus their attention where is strategic.
- The implementation and administration of outsourcing demand skills that permit to distinguish when a strategic partnership is being done or simply a business transaction.

\section{7 - Develop high-performance.}

- The area of high-performance IT should: seek operational efficiency, either in development or in the internal outsourcing.

- In the search for efficiency, often IT follows trends in the area of manufacturing, such as TQM (add up to ISO9000 for software development).

- A concern in the area of IT should be the time for development: information systems should be deployed as soon as possible (today, delays of two or three years are no longer acceptable), so they are not obstacles to the deal.

\section{8 - Re-design and administer an IT organization}

- The question "centralization vs. decentralization" culminated in the organization.

- A central IT organization to do the planning, allocation of resources and shopping with economy of scale, some autonomy for local businesses to seek their specific solutions.

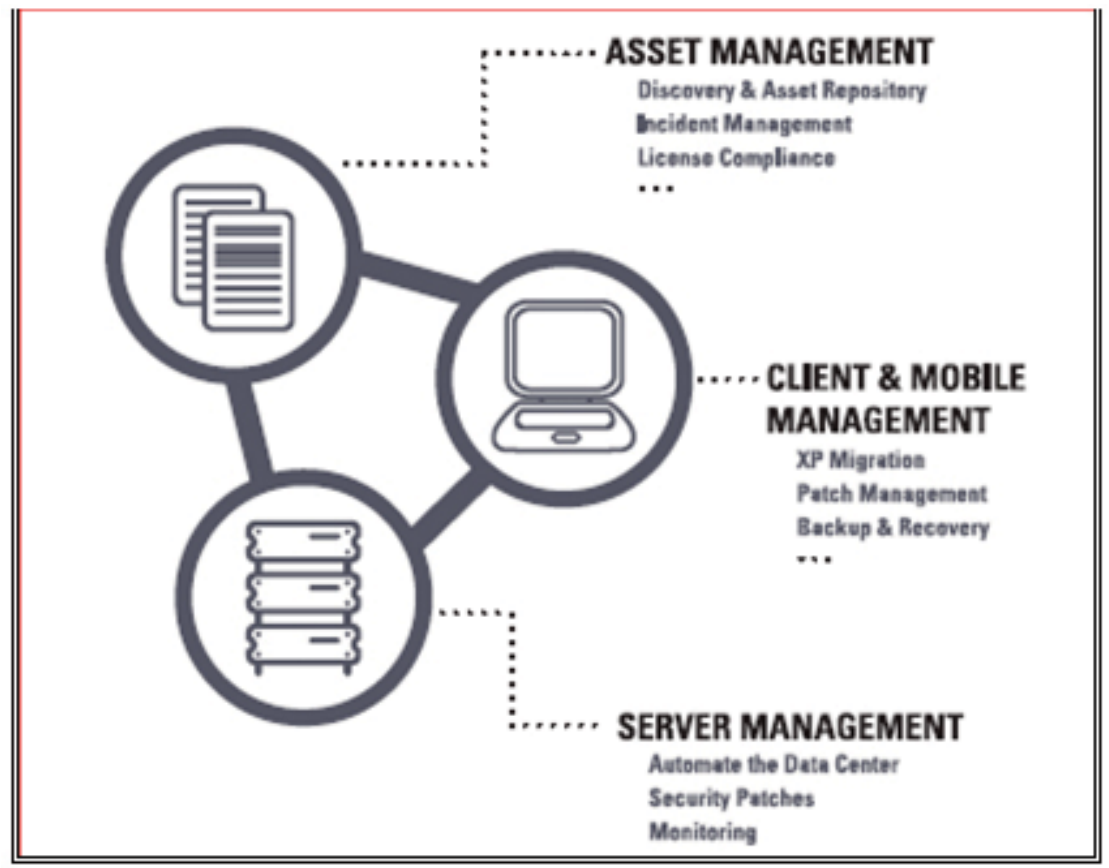

FIGURE 5 - Management of resources, clients, mobile equipment and server. Source: Altiris Inc. 
- With this structure, one can get the alignment with the business, economy of scale and integrity in systems architecture.

Figure 5 illustrates the modularity necessary for the development of the IT infrastructure, necessary for the deployment of a solution for the management of assets.

According to BROWN (2005), an integrated solution for the management of assets combines the disciplines of management resources and services of the digital company in a single architecture based on the WEB, repository and console, helping to unite various departments and processes. To actively manage the entire lifecycle of resources, the solution helps organizations to eliminate unnecessary costs for software and hardware, to proactively manage contracts with suppliers and align the resources of services with ITIL (Information Technology Infrastructure Library), to ensure optimization of IT investments. The benefits include:

- Monitor the configuration, the implemented versions, the relationships and historical information of IT resources;

- Monitor the use of software and hardware for relocation and negotiation of contracts;

- Ensure the availability of resources through the management of incidents and problems.

The management of clients and mobile equipment allow administrators to implement, manage and troubleshoot systems from anywhere. The benefits include:

- Consolidated management of desktops, notebooks and handhelds;

- Implementation of the OS (operating system) migration and personality of the PC with zero intervention;

- Comprehensive inventory of software and hardware with the generation of reports over the Internet;

- Assessment of the vulnerabilities of the system with software distribution and patch management in real time;

- Management states through the resources of auto correction and reversal of applications.

The management of servers offers the functions of implementation, management and monitoring from a centralized console, reducing the total cost of infrastructure. The benefits include:

- Improve the reliability and stability of servers, minimizing downtime of the digital company and improving user satisfaction;

- Automate the management of IT operations to respond quickly to changing needs of the digital company;

- Monitor the performance, restore the operation and minimize the security patches to ensure the continuity of the operation.

IT managers need to be increasingly involved in development, control and monitoring technology assets of their organizations. The constant pressure to keep the efficiency in IT investments shows that it is priority to manage these assets in two ways: as a function of the IT department as well as an integral part of the organization. IT management should be focused on allowing them to obtain the full potential of technology, working in four main areas: alignment with the business and services, management of complexity, strategic outsourcing and capture of value (BROWN, 2005).

The ability to leverage the potential of technology is becoming increasingly critical to the success of small and medium enterprises. The main tool to acquire this ability is to develop an effective IT organization, focusing on three key areas: the definition of an organizational structure appropriated to the business and technological environments of the company, the development of processes and skills to centralize some critical tasks, and a model of governance structured to facilitate the alignment of those responsible for service with the team of IT (BROWN, 2005).

To support these organizational changes, it also needs a strong cultural change: the information technology needs to be perceived as a competitive level and managers should feel responsible, together with IT professionals, by incorporating the technology in the services strategy. The supports of high direction, as well as the recruitment of professionals with the appropriate profile, are essential elements for achieving the change (SCHWABER, 2007)

Figure 6 shows how information technology is involved with all operational procedures of the company and, increasingly, is affecting the ability to offer services influencing the efficiency, quality of customer service and innovative capacity.

Developing the IT organization and structuring its relationship with the areas of services is the main instrument to build skills 


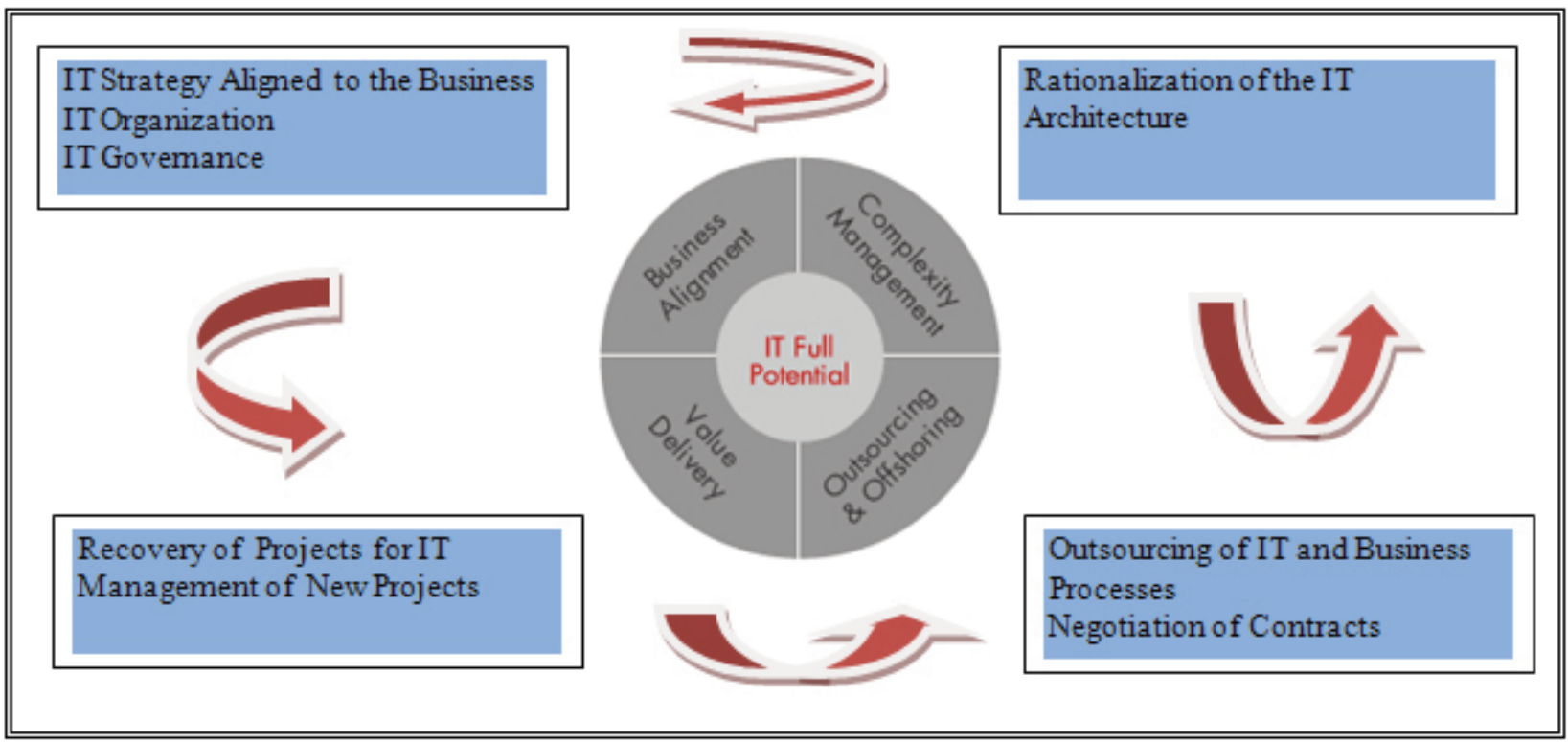

FIGURE 6 - IT Maximum Potential

Source: Bain \& Company

in IT. Analyzing the organizational models of companies that stand out in the use of technology, we point out best the practices on three key aspects to an effective organization of IT: defining the most appropriate organizational structure, functions and the critical competencies that should be centralized and governance for investments in technology (RAMIREZ, 2003)

\section{Conclusions}

To conduct, effectively, the lifecycle of assets in IT is no longer an option, it is essential. Regardless the type of asset, organizations need to understand, at least the minimum, of what was purchased, what is its value and where it is allocated. The solutions for managing the IT lifecycle include a combination of policies, processes, technologies and resources to use, monitor, serve, manage and update the hardware and software assets effectively.

The increase in the number of servers and PCs, the mobility trend reflected in a longer list of equipment (laptops, cell phones, PDAs, among others), exponential growth of Datacenter, as well as the number of departments within a company, contribute to a greater complexity in the administration of IT assets (COEN, 2004).

Additionally, organizations suffer strong pressure to meet the needs as:

- Reduction of the total cost of ownership (TCO) of assets through the optimization of procedures for the purchase, implementation, monitoring and administration;

- To manage the relationships between people and assets, by simplifying the IT workloads, human resources and finance departments;

- To simplify the process of updating software;

- To ensure good follow up and monitoring of licenses and other contractual arrangements;

- Accelerate the service and the support through proactive alerts, thus simplifying time and effort of IT administration.

The solution for managing IT lifecycle is organized on three levels over a model of maturity, as the needs of computing resources. (Figure 4)

To manage the IT assets with greater precision and integration, offers greater operational efficiency and greater control and simplification of computing resources (COEN, 2004).

Aware of this need, the IT managers need to align the company's digital strategies with the policies of deployment and use of Information Technology as essential considering the following items:

- What are the challenges faced and the paths followed by the organizations? 


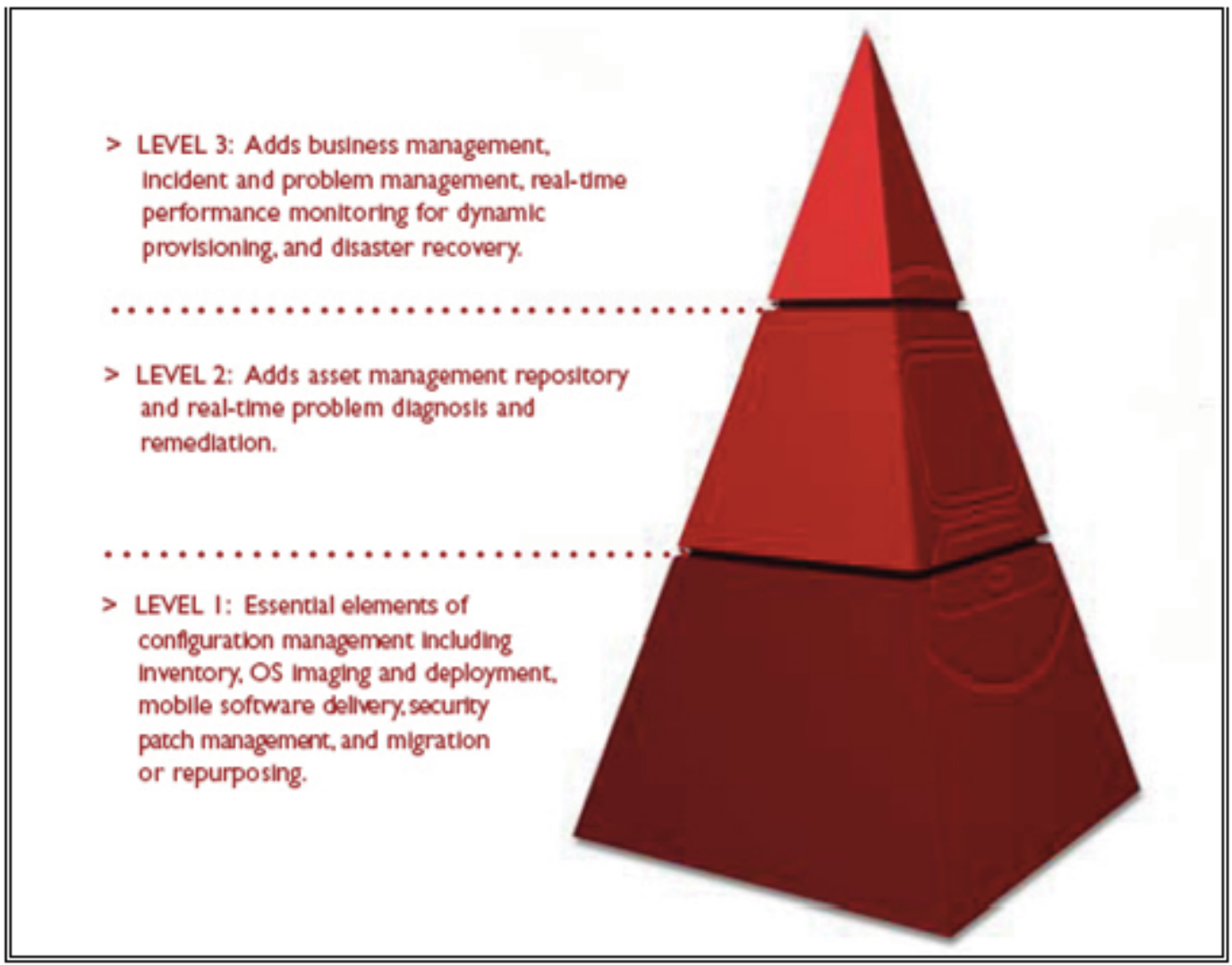

Figure 7 - Maturity Model. Source:Altiris

- What are the services offered to customers with the implementation of the practice of managing the IT cycle?

- How to manage purchasing decisions and processes of IT assets?

- How to develop predictive information and a real-time view of IT assets to improve the level of service, security and the use thereof?

- How to keep a consistency and control of costs at a deeper level of user / department?

- In what degree is your organization and what steps should it follow to optimize its practice of IT Asset Management?

The use of digital technology is evolving toward comprehensive solutions to manage IT using a single repository and a single interface, dramatically reducing the costs and complexity of managing their resources, including desktops, thin clients, laptops, handheld devices and networks. It is essential to auto- mate, simplify and integrate their functions to manage IT from a single console-based Web. Innovations in IT continue to emerge in a frenzied pace, driven by the rapid advancement of technology for semiconductors. Information is key assets of businesses in the post-industrial era. The correct investment in IT has been pressured for tangible and sustainable results and the management of IT resources is essential to corporate success (PALETTA, 2008).

The vision of management of IT assets, however, needs to be expanded at a higher level of functionality and processes, since administering assets throughout the lifecycle involves much more than counts them to reduce costs. And to manage the physical assets and software within an organization requires an approach from the technological point of view to business processes. 


\section{References}

ALTIRIS. Gerenciamento do ciclo de vida de TI. Disponível em: < http://www.altiris.com >.Acesso em: 22 set. 2008.

BROWN, A.B. A best practice approach for automating IT management process. IBM: Research Division, 2005.

CÂMARA BRASILEIRA DE COMÉRCIO ELETRÔNICO. Relatório final - vertical e-business 2005. Disponível em: <http://golden.softex.br/portal/softexweb/uploadDocuments/eBusiness.doc> Acesso em: 18 set. 2008.

CGI - COMITÊ GESTOR DA INTERNET NO BRASIL. Pesquisa sobre o uso das tecnologias da informação e da comunicação no Brasil 2007. Disponível em: < http://www.cetic.br/hosts/2008/index.htm>.Acesso em: I 3 set. 2008.

COEN, L. Gerenciamento de ativos: maior controle em TI. Disponível em: < http://www.companyweb.com.br/lista_artigos.cfm?id_artigo=192. Fev, 2004 >.Acesso em: 24 ago. 2008.

COEX, D.E., KREGER, H. Management of the service-orientedarchitecture life cycle. IBM Systems Journal, v. 44, n. 4, 2005.

CSILLAG, J.M.; GRAEML, A.R. Como as empresas brasileiras estão utilizando a TI. HSM Management Update, n. I6, jan., 2005. Disponível em: <http://www.mettodo.com.br/pdf/Como\%20as \%20empresas\%20brasileiras\%20estao\%20utilizando\%20a\%20TI. pdf.> Acesso em: I I set. 2008.

DAY, G.S.; HUBBARD, K.J. Lições sobre clientes na Internet. Revista HSM Management Update, n.43, mar./abr., 2005.

FUJITSU SERVICES. Managing the IT infrastructure for business advantage. England, s.e., 2002.

FUNDAÇÃO DE AMPARO À PESQUISA DO ESTADO DE SÃO PAULO. Indicadores de ciência, tecnologia e inovação em São Paulo 2004. São Paulo: FAPESP, 2004. p.38-42.

LAURINDO, F. J. B. Um estudo sobre a avaliação da eficácia da Tecnologia da Informação nas organizações. São Paulo, 2000. 165p. Dissertação de Mestrado. Escola Politécnica. Universidade de São Paulo. Disponível em:< http://www.poli.usp.br/pro/docentes/laurindo/doutorado_fjbl.pdf > Acesso em: 28 ago. 2008.

LOZINSKY, S. Os componentes de um projeto de tecnologia. IBM, 2003. Disponível em: <http://www.ibm.com.br> Acesso em: 25 ago. 2008.
LUCIANO, E.M.; TESTA, M.G.; FREITAS, H. As tendências em comércio eletrônico com base em recentes congressos. In: ASAMBLEA ANUAL DEL CONSEJO LATINOAMERICANO DE ESCUELAS DE ADMINISTRACIÓN - CLADEA, 38., 2I-24 oct., 2003, Lima. Lima: CLADEA/Universidad San Ignácio de Loyola, 2003.

LOZINSKY, S. Os componentes de um projeto de tecnologia. Disponível em: < http://www.ibm.com/br/services/articles/ 2003/08/a3 I m032t03s022003.shtml>Acesso em; 26 ago. 2008.

O'BRIEN, F. IT Life Cycle Management Conference. Gartner, 2002. Disponível em: <http://www.gartner.com> .Acesso em: 29 ago. 2008.

OECD - ORGANISATION FOR ECONOMIC CO-OPERATION AND DEVELOPMENT. Information Technology Outlook: ICTs and the Information Economy, 2002. Paris: OECD, 2002.

OECD - ORGANISATION FOR ECONOMIC CO-OPERATION AND DEVELOPMENT. Science, Technology and Industry Outlook 2006. Paris: OECD, 2006.

OECD - ORGANISATION FOR ECONOMIC CO-OPERATION AND DEVELOPMENT. Science, Technology and Industry: Scoreboard 2007. Innovation and Performance in the Global Economy. Paris: OECD, 2007.

PALETTA, F.C. Tecnologia da informação, inovação e empreendedorismo: fatores críticos de sucesso no uso de ferramentas de gestão em empresas incubadas de base tecnológica. 143 p. (Tese de Doutorado) - Instituto de Pesquisas Energéticas e Nucleares. Autarquia Associada à Universidade de São Paulo (USP). São Paulo, 2008.

RAMIREZ, J.C.; ZUCARELLI, G. Você tem a organização de TI certa para suportar sua estratégia de negócio? Disponível em: http://www.bain.com/bainweb/PDFs/cms/Public/Voce_tem_organizacao_de_ti_certa_Portuguese.pdf.Acesso em: I 0 set. 2008

ROCKART,J. F.; EARL, M.J.; ROSS, J.W."Eight Imperatives for the new IT Organization”. Sloan Management Review, Cambridge, v.38, n. I , p.43-55, 1996.

ROCKART, J.F.; EARL, M.J.; ROSS, J.M.“"Eight Imperatives for the new IT Organization”. Sloan Management Review, Cambrigde, v.38, n. I, p.43-55, Fall. 1996.

SCHWABER, C. Soluções abertas para o gerenciamento do ciclo de vida da aplicação (ALM) -2007- Disponível em: < http://www.borland.com/br/company/open-alm-vision.html >. Acesso em: 12 set. 2008. 
SILVER, M. Ten Major IT Asset Issues Managers Should Address. Gartner, 2003 Disponível em:< http://www.gartner.com>. Acesso em: 28 ago. 2008.

UN (ONU) - UNITED NATIONS ICT TASK FORCE. Measuring ICT :The global status of ICT Indicators. Partnership on measuring ICT for development. 2005. 176p.

VIOTTI, E.B.; MACEDO, M.M. Indicadores de ciência, tecnologia e inovação no Brasil. Campinas: Editora da Unicamp, 2003. 614p.

WESTERMAN, G.; HUNTER, R. O risco de TI: convertendo ameaças aos negócios em vantagem competitiva. São Paulo: M. Books do Brasil, 2008. 204p. 